\title{
The Investigation for Coating Method of Titanium Dioxide Layer in Perovskite Solar Cells
}

\author{
Pao-Hsun Huang ${ }^{1}\left(\right.$, , Chien-Wu Huang ${ }^{2}$, Chih-Chieh Kang ${ }^{3}$, Chia-Hsun Hsu ${ }^{4}$, \\ Shui-Yang Lien ${ }^{4,5,6, *}$, Na-Fu Wang ${ }^{7}(1)$ and Chien-Jung Huang ${ }^{2, *}$ \\ 1 School of Information Engineering, Jimei University, 183 Yinjiang Road, Jimei, Xiamen, Fujian 361021, China; \\ ph.huang@jmu.edu.cn \\ 2 Department of Applied Physics, National University of Kaohsiung, Kaohsiung University Rd., \\ Kaohsiung 81148, Taiwan; go40120@gmail.com \\ 3 Department of Electro-Optical Engineering, Southern Taiwan University of Science and Technology, \\ Nan-Tai Street, Tainan 71005, Taiwan; kangc@stust.edu.tw \\ 4 School of Opto-electronic and Communication Engineering, Xiamen University of Technology, \\ Xiamen 361024, China; chhsu@xmut.edu.cn \\ 5 Department of Materials Science and Engineering, Da-Yeh University, Changhua 51591, Taiwan \\ 6 Fujian Key Laboratory of Optoelectronic Technology and Devices, Xiamen University of Technology, \\ Xiamen 361024, China \\ 7 Department of Electronic Engineering, Center for Environment Toxin and Emerging-Contaminant Research, \\ Super Micro Mass Research \& Technology Center, Cheng Shiu University, Niaosong District, \\ Kaohsiung 81148, Taiwan; k0481@gcloud.csu.edu.tw \\ * Correspondence: sylien@xmut.edu.cn (S.-Y.L.); chien@nuk.edu.tw (C.-J.H.)
}

Received: 15 February 2020; Accepted: 19 March 2020; Published: 24 March 2020

\begin{abstract}
The effect of conventional Perovskite solar cells (PSCs) by using different concentration and spin-coating speeds of titanium dioxide $\left(\mathrm{TiO}_{2}\right)$ as an electron transport layer (ETL) was studied. The influence of $\mathrm{TiO}_{2}$ based on device structure: fluorine-doped tin oxide substrate/ $/ \mathrm{TiO}_{2} /$ Perovskite $\left(\mathrm{CH}_{3} \mathrm{NH}_{3} \mathrm{PbI}_{3}\right) / 2,2^{\prime}, 7,7^{\prime}$-Tetrakis[N,N-di(4-methoxyp phenyl)amino]-9,9'-spirobifluorene/silver, is also studied. The spin-coating speed is varied in a range from 1000 to $3000 \mathrm{rpm}$ to get optimal performance of device. The optimized power conversion efficiency (PCE) of PSCs with original concentration (OC) and double concentration (DC) $\mathrm{TiO}_{2}$ is 8.74 and $9.93 \%$, respectively. The reason is attributed to excellent absorption in shorter wavelength, compact characteristic, and suitable thickness of $\mathrm{TiO}_{2}$, leading to perfect short-circuit current density (Jsc), lower series resistance (Rs), and higher fill factor (FF) of 0.75 . Besides, recombination of electron and hole is also decreased due to the compact feature, leading to higher open-circuit voltage $\left(\mathrm{V}_{\mathrm{OC}}\right)$ of $0.91 \mathrm{~V}$.
\end{abstract}

Keywords: perovskite solar cells; titanium dioxide; concentration; spin-coating process

\section{Introduction}

People are dedicated to develop and advance photovoltaics because solar source is an emerging renewable energy with progress of technology and energy depletion. The outstanding breakthrough for solar cells is the discovery of perovskite in the Ural Mountains of Russia by Gustav Rose in 1839 and is named after Russian mineralogist Lev Perovski. Perovskite solar cells (PSCs) are a type of solar cells containing a perovskite structured compound and considered as light-harvesting active layer, most commonly a hybrid organic-inorganic lead or tin halide-based material [1-6].

In the past few years, lead halide perovskites have gained tremendous attention around the globe because of their excellent photovoltaic characteristics, including high charge carrier mobility [1], large absorption coefficient [2], and tunable optical properties [3]. Organic-inorganic hybrid solar cells based 
on lead halide perovskites have achieved a phenomenal improvement in power conversion efficiency (PCE) from $3.8 \%$ to $24.02 \%$ in ten years. The remarkable record of high PCE for perovskite solar cells can be recorded 3.8\% published by Miyasaka et al. took organometal halide perovskites as sensitizers in liquid electrolyte-based dye-sensitized solar cells (DSSCs) in 2009 [4]. In 2011, Park et al. realized an efficiency of $6.5 \%$ by applying $\mathrm{TiO}_{2}$ surface treatment prior to deposition [7]. In 2012, an all-solid-state lead iodide perovskite sensitized $\mathrm{TiO}_{2}$ mesoscopic heterojunction solar cell with long-term stability had achieved a PCE of 9.7\% [8]. In 2013, an outstanding PCE of 15\% received from perovskite-sensitized mesoscopic solar cells was prepared using the sequential deposition method [9]. The astonished breakthrough of outstanding PCE is to reach 20.1\%, published by Bakr et al. in 2015 [5]. Moreover, it is worth mentioning that there are some research groups devoted to apply perovskite solar cells on flexible substrates to develop wearable devices for illumination, exercise, etc., $[10,11]$. The DSSCs has been studied by a lot of researchers since Gratzel reported a DSSC device with sandwich-mode architecture in 1991 [12]. The traditional DSSC structure includes a dye-sensitized photoanode, a counter electrode, and an electrolyte [13]. The photoanode includes a $\mathrm{TiO}_{2}$ porous film and a $\mathrm{TiO}_{2}$ compact film [14]. The $\mathrm{TiO}_{2}$ compact layer is conventionally prepared by many methods as following: aerosol spray pyrolysis [15-17], thermal oxidation [18], spin-coating method [14], atomic layer deposition [19], and electrochemical deposition [20]. Besides, $\mathrm{TiO}_{2}$ film is a promise candidate to act as an electron transport layer (ETL) in PSCs according to best absorption at short wavelengths [21-23].

In this study, we discuss the performance of PSCs with different concentration and various spin-coating speeds of $\mathrm{TiO}_{2}$ to understand the fundamental effect. The $\mathrm{TiO}_{2}$ solution is prepared with original and double concentration, however, grown $\mathrm{TiO}_{2}$ film is also fabricated at 1000, 2000, and $3000 \mathrm{rpm}$. The properties of $\mathrm{TiO}_{2}$ film and improved PSCs are also researched to further optimize PCE.

\section{Materials and Methods}

In this paper, all materials were purchased by commercial source and used without further sublimation to accomplish fabrication. All preparation of solution and thin film was continuously achieved in glove box. The cleaning process of substrate was referred and complied with standard operation procedure of previous researches. The work function of fluorine-doped tin oxide-coated glass substrates (FTO-glass, with a sheet resistance of $7 \Omega / \mathrm{sq}$, AimCore Technolog, Hsinchu, Taiwan) was improved by treatment of oxygen $\left(\mathrm{O}_{2}\right)$ plasma with $10 \mathrm{~W}$ for $2 \mathrm{~min}$ [24] to reduce carbon contamination and effectively grow subsequent thin film.

\subsection{Precursors Preparation}

The prescription of $\mathrm{TiO}_{2}$ precursor solution consisted of titanium isopropoxide ( $369 \mu \mathrm{L}$ for original concentration; $738 \mu \mathrm{L}$ for double concentration) diluting in isopropanol $(2.53 \mathrm{~mL})$ and $\mathrm{HCl}$ solution ( $35 \mu \mathrm{L}$ of $2 \mathrm{M}$ ) diluting in isopropanol $\left(2.53 \mathrm{~mL}\right.$ ). Then, $\mathrm{HCl}$ solution was dropwise added into $\mathrm{TiO}_{2}$ precursor solution under stirring at $300 \mathrm{rpm}$ for $24 \mathrm{~h}$ and filtered with a PTFE filter with $0.2 \mu \mathrm{m}$ pore size before use. The prescription of perovskite precursor solution consisted of $\mathrm{PBI}_{2}(1.25 \mathrm{M}, 99.99 \%$, Alfa Aesar, Haverhill, MA, USA) and $\mathrm{CH}_{3} \mathrm{NH}_{3} \mathrm{I}(1.25 \mathrm{M},>98 \%$, Dyesol, Queanbeyan, Australia) (i.e., $\mathrm{PBI}_{2}$ of $576.25 \mathrm{mg}, \mathrm{CH}_{3} \mathrm{NH}_{3} \mathrm{I}$ of $198.75 \mathrm{mg}$ ) in mixing solvent (1 mL, where volume ratio of dimethyl sulfoxide (DMSO) to $\gamma$-butyrolactone (GBL) is 1:1) [25]. Perovskite precursor solution was kept stirring at $300 \mathrm{rpm}$ for $24 \mathrm{~h}$ and then filtered with PTFE filter of $0.2 \mu \mathrm{m}$ pore size before use. The spiro-OMeTAD solution was prepared by blending two solution, 4-tert-butylpyridine (tBP) solution (tBP of $28.5 \mu \mathrm{L}$ with spiro-OMeTAD of $80 \mathrm{mg}$ in chlorobenzene $(1 \mathrm{~mL})$ ) and lithium-bis(trifluoromethanesulfonyl)imide (Li-TFSI) solution of $17.5 \mu \mathrm{L}$ (Li-TFSI of $520 \mathrm{mg}$ solved in acetonitrile $(1 \mathrm{~mL})$, which is prepared under stirring at $300 \mathrm{rpm}$ for $24 \mathrm{~h}$ before dropwise into tBP solution).

\subsection{Fabrication of Thin Film and Device}

The $\mathrm{TiO}_{2}$ precursor solution was dynamically spin-coated onto FTO substrates at different coating speeds $(1000 / 2000 / 3000 \mathrm{rpm})$ for $60 \mathrm{~s}$ and heated at $180^{\circ} \mathrm{C}$ for $5 \mathrm{~min}$ on hotplate in air to grow $\mathrm{TiO}_{2}$ thin 
film. $\mathrm{TiO}_{2}$ thin film was annealed at $550{ }^{\circ} \mathrm{C}$ for $30 \mathrm{~min}$ to form compact characteristic. The perovskite layer prepared by mixing solvent was deposited using solvent-engineering technique [25]. Perovskite precursor solution was spin-coated onto $\mathrm{TiO}_{2} / \mathrm{FTO}$ substrate in two consecutive spin-coating steps at $1000 \mathrm{rpm}$ of $10 \mathrm{~s}$ and $5000 \mathrm{rpm}$ of $20 \mathrm{~s}$ in order. During second step, toluene was dropping onto the wet spinning film. Perovskite thin film was annealed at $90^{\circ} \mathrm{C}$ for $15 \mathrm{~min}$ on hotplate before hole transport layer was deposited by spin-coating spiro-OMeTAD solution at $3000 \mathrm{rpm}$ for $30 \mathrm{~s}$. Finally, silver (Ag) metal as anode, which is defined by shadow mask with active area of $6 \mathrm{~mm}^{2}$, was deposited to thicknesses of $100 \mathrm{~nm}$ by vacuum thermal evaporation below pressure of $4.8 \times 10^{-6}$ torr. The deposition rate was monitored and adjusted by quartz crystal oscillator to ensure film thickness

\subsection{Characteristic Measurement}

All measurements were carried out in air. The current density-voltage (J-V) characteristics of device were measured with power source meter (Keithley 2400, Keithley, Cleveland, AL, USA) under an illumination of $100 \mathrm{~mW} / \mathrm{cm}^{2}$ with an AM 1.5G sun simulator (Oriel 96000 150W Xe lamp, Newport, Taipei, Taiwan). The light intensity was calibrated by reference solar cell and meter (Oriel 91150, Newport, Taipei, Taiwan). The spectrum was taken for $-5 \mathrm{~V}$ sample bias to separate sample and secondary edge for analyzer. The samples were measured by field-emission scanning electron microscopy (SEM, JEOL JSM-7001, Japan) and X-ray diffraction (XRD, ultima IV, Rigaku Corporation, Tokyo, Japan) to demonstrate cross-section images and crystalline structure, respectively. Devices were further measured by atomic force microscope (AFM, XE-70, Park Systems, Suwon, Korea) to analyze surface morphology with scan rate of $0.5 \mathrm{~Hz}$ probing an area of $10 \times 10 \mu \mathrm{m}^{2}$, with effectively reducing speed at which the tip moves and allowing system more time to adjust to sudden changes in height, and by spectrophotometer (UV-3900, Hitachi, Tokyo, Japan) to analyze the absorption spectrum and transmittance of devices. The external quantum efficiency (EQE, QE-3000, Titan Electro-Optics, Taipei, Taiwan) measurement was performed on irradiation of $150 \mathrm{~W}$ xenon light tower in DC mode.

\section{Results and Discussion}

In this study, both energy band diagram and structure are shown in Figure 1. Conventional structure of PSCs is fabricated as following: $\mathrm{FTO} / \mathrm{TiO}_{2} /$ perovskite $\left(\mathrm{CH}_{3} \mathrm{NH}_{3} \mathrm{PbI}_{3}\right) /$ spiro-OMeTAD/Ag in Figure 1a. The transportation of electron can be clear to understand owing to suitable lowest unoccupied molecular orbital of $\mathrm{TiO}_{2}$ in Figure $1 \mathrm{~b}$. Figure 2 shows current density-voltage (J-V) characteristic of devices obtained by $\mathrm{TiO}_{2}$ with original concentration (OC) and double concentration (DC) at various spin-coating speeds (1000, 2000, and $3000 \mathrm{rpm})$, corresponding to red, blue, and purple line, respectively. We can clearly see red line have a colossal area under intersection of $x$ and y-coordinate compared to others. Generally speaking, the fill factor (FF) is determined from the intersection of area when J-V curve has been achieved. It is obviously shown that device performance prepared by $\mathrm{OC} \mathrm{TiO}_{2}$ is not improved when coating speed is increased by two and three times in Figure 2a. The same situation and results occur in device prepared by $\mathrm{DC}^{\mathrm{TiO}_{2}}$ in Figure $2 \mathrm{~b}$. The optimized power conversion efficiency (PCE) of device prepared by $\mathrm{OC}$ and $\mathrm{DC} \mathrm{TiO}_{2}$ is 8.74 and 9.93\% with $1000 \mathrm{rpm}$, respectively. Poor PCE of device prepared by OC and $\mathrm{DC}^{\mathrm{TiO}}{ }_{2}$ is only 0.77 and $1.2 \%$ with $3000 \mathrm{rpm}$, respectively. The higher series resistance (Rs) $\left(6290 \Omega \mathrm{cm}^{2}\right.$ and $\left.728 \Omega \mathrm{cm}^{2}\right)$ and lower FF (0.14 and 0.15) are one of the active factors to cause poor performance in Table 1 . The Table 1 presents detailed performance of all devices. It can convey information about differences between $\mathrm{OC}$ and $\mathrm{DC} \mathrm{TiO}_{2}$, and effect on various speed of spin-coating fabrication. As coating speed decreases one times, the PCE of device prepared by $\mathrm{OC} \mathrm{TiO}_{2}$ is enhanced from 4.38 to $8.74 \%$ because of a great increase in short-circuit current density $\left(\mathrm{J}_{\mathrm{SC}}\right.$ ) from 7.58 to $19.21 \mathrm{~mA} / \mathrm{cm}^{2}$, indicating that the ability of electron transport is enhanced when thickness of $\mathrm{TiO}_{2}$ gradually increases. Similar improvement of PCE is obtained by $\mathrm{DC} \mathrm{TiO}_{2}$, from 7.4 to $9.93 \%$. 


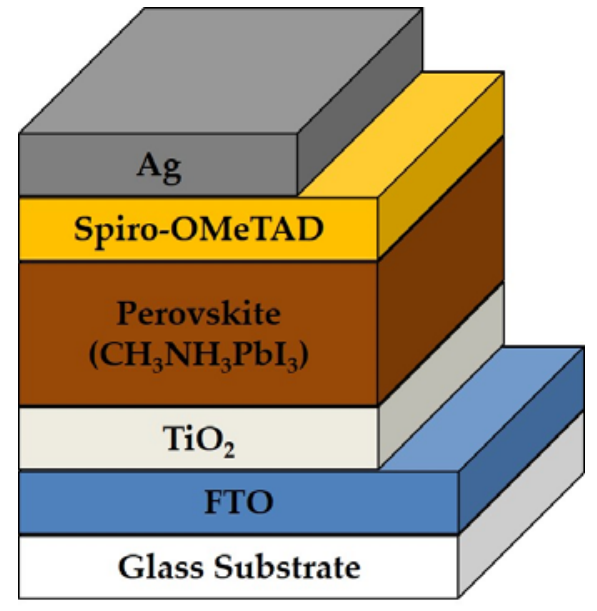

(a)

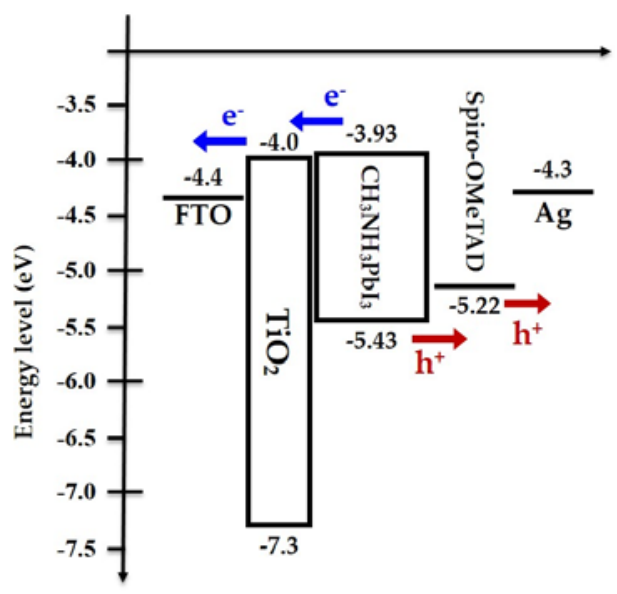

(b)

Figure 1. (a) Schematic structure of device and (b) energy level diagram of device in this study.



(a)

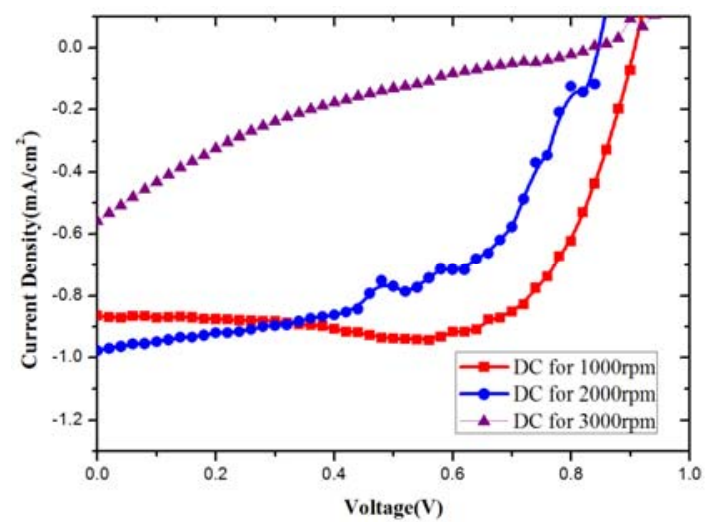

(b)

Figure 2. The current density-voltage $(\mathrm{J}-\mathrm{V})$ curves of device with different spin-coating speed of (a) original concentration (OC) $\mathrm{TiO}_{2}$ and (b) double concentration (DC) $\mathrm{TiO}_{2}$.

Table 1. Photovoltaic performance of perovskite solar cells with different $\mathrm{TiO}_{2}$ concentration and various spin-coating speeds.

\begin{tabular}{|c|c|c|c|c|c|}
\hline Sample & $\mathrm{J}_{\mathrm{sc}}\left(\mathrm{mA} / \mathrm{cm}^{2}\right)$ & $\mathrm{V}_{\mathrm{oc}}(\mathrm{V})$ & FF & $\operatorname{Rs}\left(\Omega \mathrm{cm}^{2}\right)$ & PCE (\%) \\
\hline $\mathrm{OC}^{1}$ for $3000 \mathrm{rpm}$ & 6.51 & 0.85 & 0.14 & 6290 & 0.77 \\
\hline $\mathrm{OC}^{1}$ for $2000 \mathrm{rpm}$ & 7.58 & 0.91 & 0.63 & 173 & 4.38 \\
\hline $\mathrm{OC}^{1}$ for $1000 \mathrm{rpm}$ & 19.21 & 0.88 & 0.52 & 282 & 8.74 \\
\hline $\mathrm{DC}^{2}$ for $3000 \mathrm{rpm}$ & 9.31 & 0.85 & 0.15 & 728 & 1.20 \\
\hline $\mathrm{DC}^{2}$ for $2000 \mathrm{rpm}$ & 16.29 & 0.85 & 0.53 & 142 & 7.40 \\
\hline $\mathrm{DC}^{2}$ for $1000 \mathrm{rpm}$ & 14.41 & 0.91 & 0.75 & 107 & 9.93 \\
\hline
\end{tabular}

However, it is seen that both $\mathrm{JSC}_{\mathrm{SC}}$ and Rs are affected in Table 1, indicating a two times increase in $\mathrm{TiO}_{2}$ concentration can cause improvement in PCE. Then, JSC of device is improved from 7.58 to $16.29 \mathrm{~mA} / \mathrm{cm}^{2}$ at $2000 \mathrm{rpm}$ and from 6.51 to $9.31 \mathrm{~mA} / \mathrm{cm}^{2}$ at $3000 \mathrm{rpm}$, respectively. It is also shown that all Rs results caused by $\mathrm{TiO}_{2}$ concentration of two times give an individual drop at each speed from 282 to $107 \Omega \mathrm{cm}^{2}$, from 173 to $142 \Omega \mathrm{cm}^{2}$, and from 6290 to $728 \Omega \mathrm{cm}^{2}$, respectively. In order to find 
the reason why $\mathrm{TiO}_{2}$ influences the performance of PSCs, we decided to measure EQE spectrum and compare the two devices with highest PCE in Figure 3.

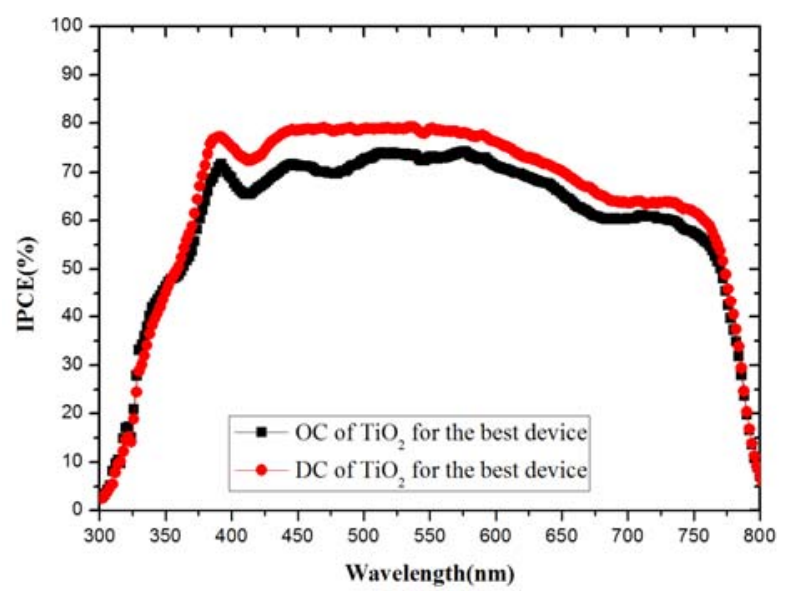

Figure 3. The external quantum efficiency (EQE) spectrum of best device from 300 to $800 \mathrm{~nm}$. The black curve is device obtained by $\mathrm{OC} \mathrm{TiO}_{2}$ and red curve is device obtained by $\mathrm{DC} \mathrm{TiO}_{2}$.

EQE spectrum of optimized device is demonstrated in Figure 3. Figure 3 displays which range of wavelength has greatest effect. The black and red curve represent the optimized device of OC and DC $\mathrm{TiO}_{2}$, respectively, reaching a maximum of $74.27 \%$ in $576 \mathrm{~nm}$ and $79.27 \%$ in $234 \mathrm{~nm}$. Two curves have increased significantly from 300 to $390 \mathrm{~nm}$ and decreased until $800 \mathrm{~nm}$. From 390 to $610 \mathrm{~m}$, black curve can reach about $71.33 \%$ of EQE in average. From 380 to $650 \mathrm{~nm}$, red curve can reach about $76.66 \%$ of EQE in average. The difference between current density from EQE data is close to that obtained from $\mathrm{J}-\mathrm{V}$ curves in Table 1 . Therefore, the current density data are reliable to explain why PCE of DC $\mathrm{TiO}_{2}$ device is higher than that of the $\mathrm{OC}$ one. Furthermore, we use absorption and transmission spectrum to further describe the relationship between light importance and device performances.

Figure 4 illustrates the UV-vis absorption and transmission spectrum of device prepared by OC and $\mathrm{DC} \mathrm{TiO}_{2}$ ETL at various spin-coating speeds in visible range from $300 \mathrm{~nm}$ to $800 \mathrm{~nm}$, respectively. All curves can be divided into two parts, in which black (1000 rpm), red (2000 rpm), and blue lines

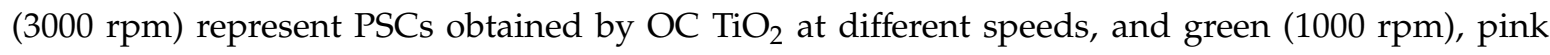
(2000 rpm), and brown lines (3000 rpm) represent that of DC one. It is obvious that absorption intensity of $\mathrm{DC} \mathrm{TiO}_{2}$ parts are higher than that of $\mathrm{OC} \mathrm{TiO}_{2}$, leading to better capability to absorb light source and then convert it to PCE. As we know, $\mathrm{TiO}_{2}$ is a wide band gap semiconductor, which has a strong absorption at short wavelengths $[23,24]$. The order of intensity for all curves with peak position are arranged as following: black $(0.724$ a.u. in $300 \mathrm{~nm})$, green $(0.662$ a.u. in $312 \mathrm{~nm})$, red ( 0.549 a.u. in $300 \mathrm{~nm}$ ), pink (0.543 a.u. in $312 \mathrm{~nm})$, brown ( 0.473 a.u. in $312.5 \mathrm{~nm})$, and blue (0.291 a.u. in $300.5 \mathrm{~nm}$ ). Compared to the average intensity of absorption spectrum, $\mathrm{DC}^{-\mathrm{TiO}_{2}}$ film is 0.559 a.u., which is higher than 0.521 a.u. of $\mathrm{OC}^{\mathrm{TiO}} 2$ film. Therefore, more light has been absorbed when PSCs are fabricated by DC $\mathrm{TiO}_{2}$ ETL. Further cross-section images of optimized PSCs obtained by DC $\mathrm{TiO}_{2}$ ETL are indicated by measurement of SEM in Figure 5. The thickness of each layer can be demonstrated and cross-section image of SEM is further measured via rotate and zero angle. The surface roughness (Rq) and morphologies of OC and $\mathrm{DC} \mathrm{TiO}_{2}$ film coated on FTO substrate are shown in Figure 6. The difference of $\mathrm{Rq}$ is too close (maximum and minimum value is 29.892 and $22.254 \mathrm{~nm}$, respectively) and all values are listed in Table 2. As shown in Figure 6a-d, these surfaces are compact due to island distribution, compared to the result of columnar distribution in Figure 6e,f.

Figure 7a shows the XRD spectra of $\mathrm{OC} \mathrm{TiO}_{2}$ film fabricated on FTO substrate. No extra peak of $\mathrm{OC} \mathrm{TiO}_{2}$ film is produced due to basic peaks of FTO substrate, indicating the ability of electron transportation is affected by surface roughness at interface between Perovskite and $\mathrm{TiO}_{2}$. However, although the difference of surface roughness is not huge in Table 2, morphology of $\mathrm{DC}^{-\mathrm{TiO}_{2}}$ film at 
$1000 \mathrm{rpm}$ is more compact to others in Figure 6d. The unexpected crystallite growths because a small peak of $\mathrm{DC} \mathrm{TiO}_{2}$ film is found at $2 \theta=26^{\circ}$, which represents tetragonal anatase structure (JCPSD card no. 83-2243) in Figure 7b.

We ascribe the growth factor of tetragonal anatase structure to annealing temperature of $90{ }^{\circ} \mathrm{C}$ but there is no sufficient evidence to demonstrate [25]. So, the reason for PCE improvement is attributed not only to absorb light contribution of short wavelength from $\mathrm{TiO}_{2}$ film but effective blocking of recombination between electron and hole in $\mathrm{TiO}_{2}$ film, leading to enhancement of open-circuit $\left(\mathrm{V}_{\mathrm{OC}}\right)$ from 0.85 to $0.91 \mathrm{~V}$. When spin-coating speed decreases, the thickness is gradually thinner and the ability of electron transportation is also increased, corresponding to boost JSC and FF in Table 1. Therefore, better PCE of $8.74 \%$ and $9.93 \%$ are achieved with thinner OC and DC $\mathrm{TiO}_{2}$ at $1000 \mathrm{rpm}$ (average value of $55.33 \mathrm{~nm}$ ), respectively. In the future, we predict that the thickness and crystalline characteristic of compact layer is the most important factor to affect the performance of PSCs because charge transport would be largely enhanced by suitable $\mathrm{TiO}_{2}$ layer.

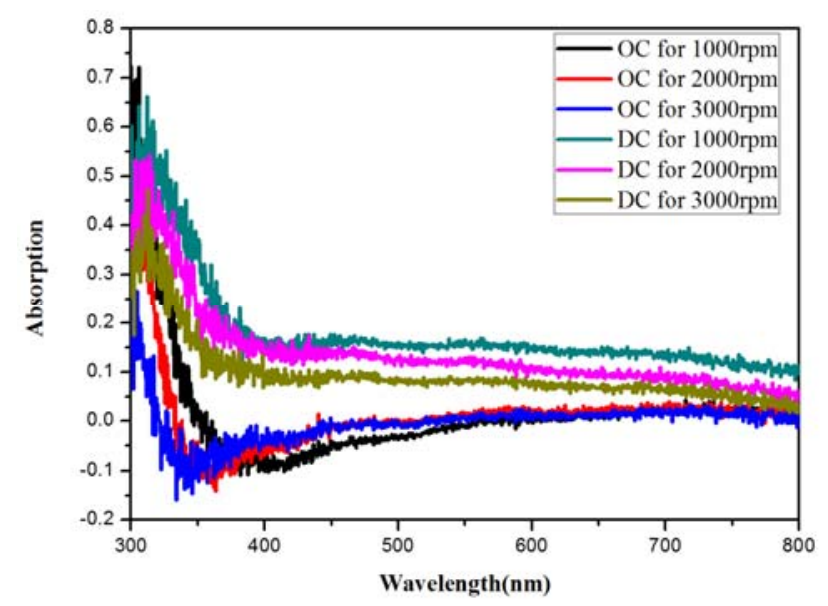

Figure 4. The UV-vis absorption spectrum of original and double concentration of $\mathrm{TiO}_{2}$ in various spin-coating speeds.

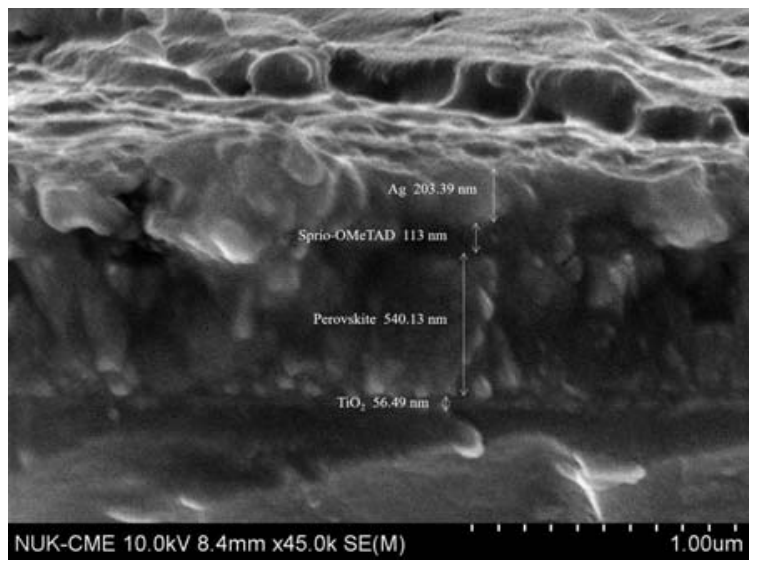

(a)

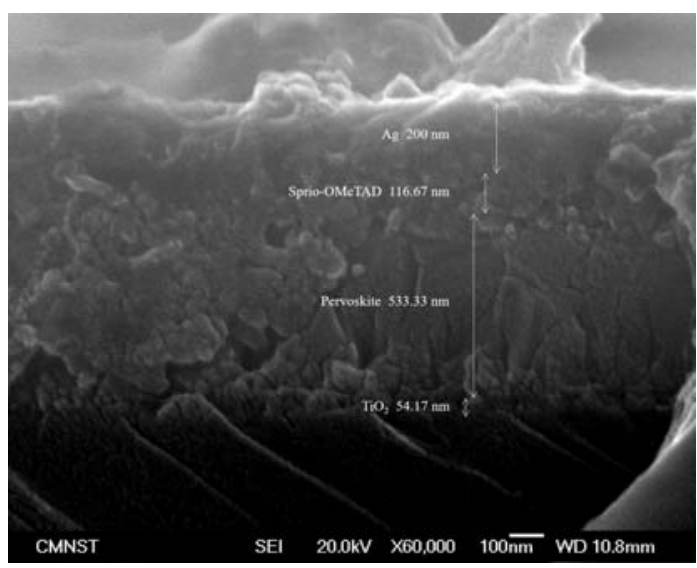

(b)

Figure 5. The cross-section images of SEM with (a) rotate and (b) zero angle for optimized PSCs obtained by $\mathrm{DC} \mathrm{TiO}_{2}$ ETL. 


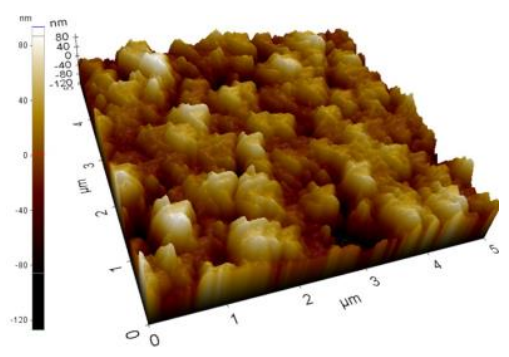

(a) $\mathrm{OC} \mathrm{TiO}_{2}$ film (1000 rpm)

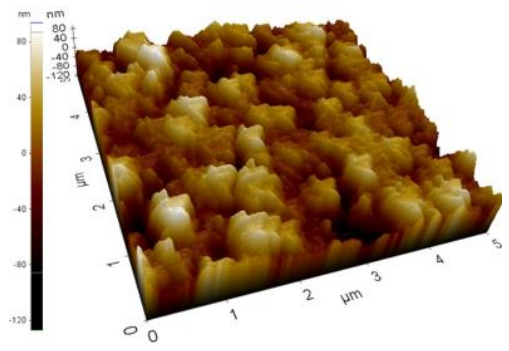

(d) $\mathrm{DC} \mathrm{TiO}_{2}$ film (1000 rpm)



(b) $\mathrm{OC} \mathrm{TiO}_{2}$ film (2000 rpm)

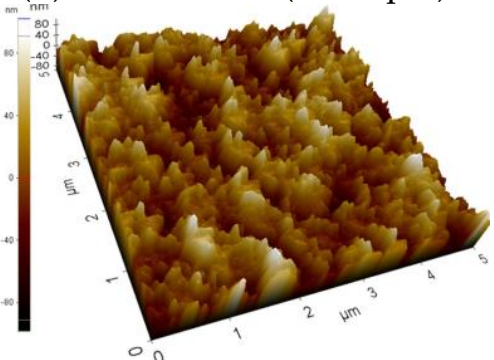

(e) $\mathrm{DC} \mathrm{TiO}_{2}$ film $(2000 \mathrm{rpm})$

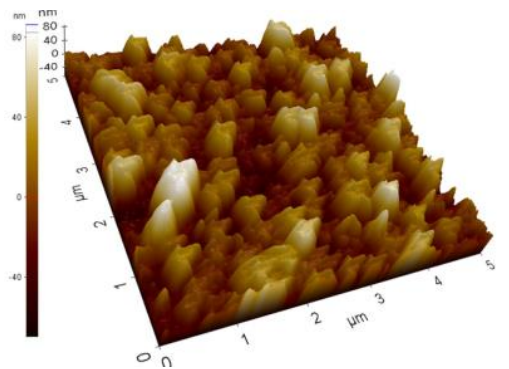

(c) $\mathrm{OC} \mathrm{TiO}_{2}$ film (3000 rpm)

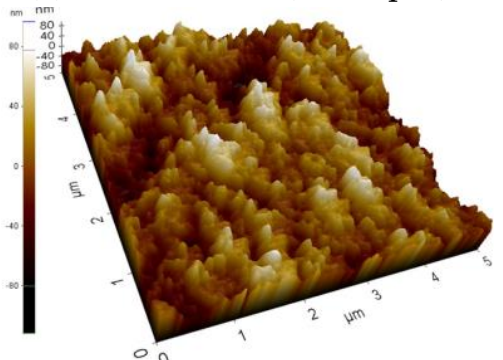

(f) $\mathrm{DC} \mathrm{TiO}_{2}$ film (3000 rpm)

Figure 6. The surface morphologies of atomic force microscope (AFM) with different spin-coating speeds based on $\mathrm{OC} \mathrm{TiO}_{2}$ film from (a) to (c) and $\mathrm{DC} \mathrm{TiO}_{2}$ film from (d) to (f).

Table 2. Surface roughness from AFM measurement for $\mathrm{OC}$ and $\mathrm{DC} \mathrm{TiO}_{2}$ film.

\begin{tabular}{ccccccc}
\hline Sample & \multicolumn{3}{c}{ OC $^{\mathbf{1}}$ Film } & \multicolumn{3}{c}{ DC $^{\mathbf{2}}$ Film } \\
\hline Speed (rpm) & 1000 & 2000 & 3000 & 1000 & 2000 & 3000 \\
Rq (nm) & 22.254 & 23.953 & 23.792 & 29.892 & 28.239 & 26.95 \\
\hline
\end{tabular}

${ }^{1} \mathrm{OC}$ means original concentration. ${ }^{2} \mathrm{DC}$ means double concentration.

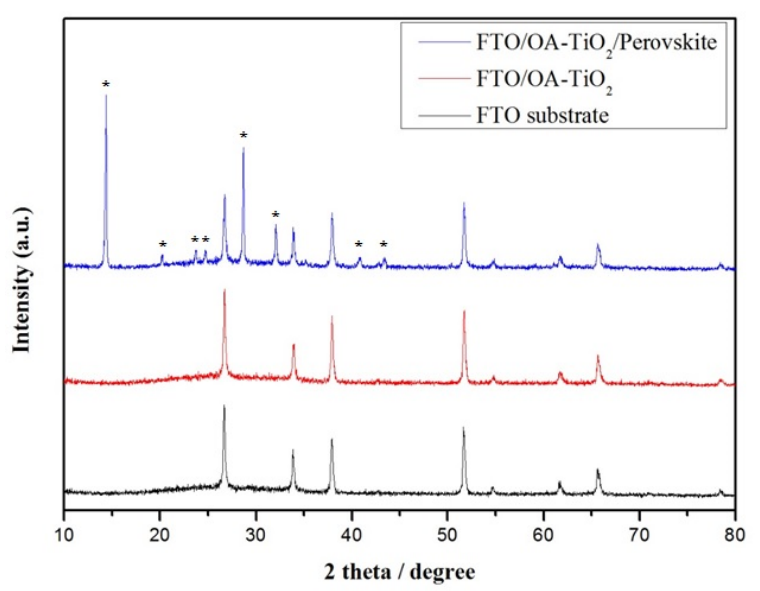

(a)

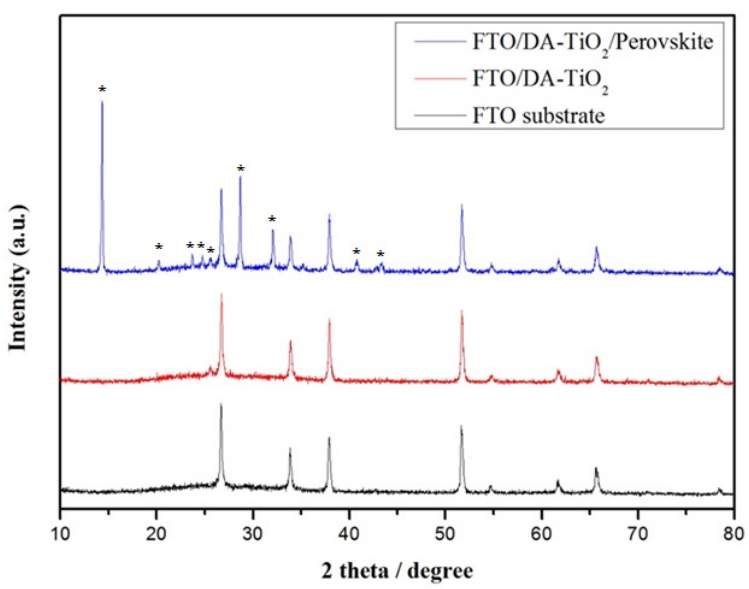

(b)

Figure 7. XRD results of (a) $\mathrm{OC} \mathrm{TiO}_{2}$ film and (b) $\mathrm{DC} \mathrm{TiO}_{2}$ film fabricated on fluorine-doped tin oxide (FTO) substrate.

\section{Conclusions}

The PSCs have been fabricated with different concentration $\left(\mathrm{OC}\right.$ and $\left.\mathrm{DC} \mathrm{TiO}_{2}\right)$ and with various spin-coating speeds. The effect of $\mathrm{TiO}_{2}$ on electron transportation has been studied via photovoltaic characteristic with AFM and XRD in this study. It is found that the main reason for highest PCE of 
PSCs obtained by OC and $\mathrm{DC} \mathrm{TiO}_{2}$ is attributed to light absorption at a shorter wavelength and more compact surface of $\mathrm{TiO}_{2}$ film, indicating the improvement of $\mathrm{J}_{\mathrm{SC}}$ and FF, respectively. The contribution can be further shown in absorption spectra and surface roughness. Although there is no enough information to prove why and how extra crystalline of $26^{\circ}$ in XRD is grown, it is still another factor for increase in PCE. The recombination of electron and hole also decreases according to compact $\mathrm{DC} \mathrm{TiO}_{2}$ film, leading to enhancement of $\mathrm{V}_{\mathrm{OC}} 0.85$ to $0.91 \mathrm{~V}$. Therefore, optimized $\mathrm{TiO}_{2}$ film as ETL in PSCs have two features as following: thin and compact. Finally, the slight change in concentration of $\mathrm{TiO}_{2}$ have attained excellent performance of PSCs when we find the suitable parameters and details of improved thin films.

Author Contributions: C.-J.H. contributed to funding acquisition; P.-H.H., C.-W.H., and C.-H.H. proposed research frame and designed experiments; C.-W.H. performed the experiments; P.-H.H., C.-W.H., and C.-H.H. analyzed materials and all authors discussed data; C.-C.K., C.-J.H., and S.-Y.L. contributed to the analysis tools and advised on results of experiment; P.-H.H. wrote the paper; P.-H.H. and C.-W.H. are responsible for submission of manuscript and subsequent procedure. Data curation, C.-W.H., C.-H.H., S.-Y.L. and N.-F.W. All authors have read and approved of published version of manuscript.

Funding: This work is sponsored by Ministry of Science and Technology (MOST) of Taiwan, Republic of China under contract number: 108-2221-E-390-006. This work is also sponsored by Science and Technology Project of Xiamen, China (No. 3502ZCQ20191002).

Conflicts of Interest: The authors declare no conflict of interest.

\section{References}

1. Kagan, C.R. Organic-Inorganic hybrid materials as semiconducting channels in thin-film field-effect transistors. Science 1999, 286, 945-947. [CrossRef]

2. Huang, P.H.; Wang, Y.H.; Ke, J.C.; Huang, C.J. The effect of solvents on the performance of $\mathrm{CH}_{3} \mathrm{NH}_{3} \mathrm{PbI}_{3}$ perovskite solar cells. Energies 2017, 10, 599. [CrossRef]

3. Kulkarni, S.A.; Baikie, T.; Boix, P.P.; Yantara, N.; Mathews, N.; Mhaisalkar, S.G. Band gap tuning of lead halide perovskites using a sequential deposition process. J. Mater. Chem. A 2014, 2, 9221-9225. [CrossRef]

4. Kojima, A.; Teshima, K.; Shirai, Y.; Miyasaka, T. Organometal halide perovskites as visible-light sensitizers for photovoltaic cells. J. Am. Chem. Soc. 2009, 131, 6050. [CrossRef]

5. Shi, D.; Adinol, V.; Comin, R.; Yuan, M.; Alarousu, E.; Buin, A.; Chen, Y.; Hoogland, S.; Rothenberger, A.; Katsiev, K.; et al. Low trap-state density and long carrier diffusion in organolead trihalide perovskite single crystals. Science 2015, 347, 519-522. [CrossRef]

6. Collavini, S.; Völker, S.F.; Delgado, J.L. Understanding the outstanding power conversion efficiency of perovskite-based solar cells. Angew. Chem. Int. Ed. 2015, 54, 9757-9759. [CrossRef]

7. Im, J.H.; Lee, C.R.; Lee, J.W.; Park, S.W.; Park, N.G. 6.5\% efficient perovskite quantum-dot-sensitized solar cell. Nanoscale 2011, 3, 4088-4093. [CrossRef]

8. Kim, H.S.; Lee, C.R.; Im, J.H.; Lee, K.B.; Moehl, T.; Marchioro, A.; Moon, S.J.; Humphry-Baker, R.; Yum, J.H.; Moser, J.E.; et al. Lead iodide perovskite sensitized all-solid-state submicron thin film mesoscopic solar cell with efficiency exceeding 9\%. Sci. Rep. 2012, 2, 591. [CrossRef]

9. Burschka, J.; Pellet, N.; Moon, S.; Humphry-Baker, R.; Gao, P.; Nazeeruddin, M.K.; Gratzel, M. Sequential deposition as a route to high-performance perovskite-sensitized solar cells. Nature 2013, 499, 316-319. [CrossRef]

10. Docampo, P.; Ball, J.M.; Darwich, M.; Eperon, G.E.; Snaith, H.J. Efficient organometal trihalide perovskite planar-heterojunction solar cells on flexible polymer substrates. Nat. Commun. 2013, 4, 1-6. [CrossRef]

11. You, J.; Hong, Z.; Yang, Y.; Chen, Q.; Cai, M.; Song, T.; Chen, C.; Lu, S.; Liu, Y.; Zhou, H.; et al. Low-temperature solution-processed perovskite solar cells with high efficiency and flexibility. ACS Nano 2014, 8, 1674-1680. [CrossRef]

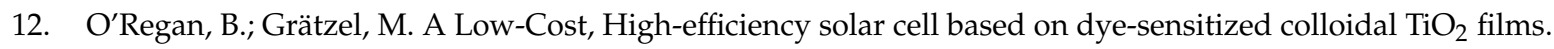
Nature 1991, 353, 24. [CrossRef]

13. Grätzel, M. Dye-sensitized solar cells. J. Photochem. Photobiol. C 2003, 4, 145-153. [CrossRef] 
14. Ke, W.J.; Fang, G.J.; Lei, H.W.; Qin, P.L.; Tao, H.; Zeng, W.; Wang, J.; Zhao, X.Z. An efficient and transparent $\mathrm{CuS}$ nanosheet film counter electrode for bifacial quantum-dot-sensitized solar cells. J. Power Sources 2014, 248, 809-815. [CrossRef]

15. Unger, E.L.; Spadavecchia, F.; Nonomura, K.; Palmgren, P.; Cappelletti, G.; Hagfeldt, A.; Johansson, E.M.; Boschloo, G. Effect of the preparation procedure on the morphology of thin $\mathrm{TiO}_{2}$ Films and their device performance in small-molecule bilayer hybrid solar cells. ACS Appl. Mater. Interfaces 2012, 4, 5997-6004. [CrossRef]

16. Kavan, L.; Tétreault, N.; Moehl, T.; Gratzel, M. Electrochemical characterization of $\mathrm{TiO}_{2}$ blocking layers for dye-sensitized solar cells. J. Phys. Chem. C 2014, 118, 16408-16418. [CrossRef]

17. Cameron, P.J.; Peter, L.M. Characterization of titanium dioxide blocking layers in dye-sensitized nanocrystalline solar cells. J. Phys. Chem. B 2003, 107, 14394-14400. [CrossRef]

18. Xia, J.B.; Masaki, N.; Jiang, K.J.; Yanagida, S. Deposition of a thin film of $\mathrm{TiO}_{\mathrm{x}}$ from a titanium metal target as novel blocking layers at conducting glass/ $\mathrm{TiO}_{2}$ interfaces in ionic liquid mesoscopic $\mathrm{TiO}_{2}$ dye-sensitized solar cells. J. Phys. Chem. B 2006, 110, 25222-25228. [CrossRef]

19. Chandiran, A.K.; Yella, A.; Stefik, M.; Heiniger, L.P.; Comte, P.; Nazeeruddin, M.K.; Graatzel, M. Low-temperature crystalline titanium dioxide by atomic layer deposition for dye-Sensitized solar cells. ACS Appl. Mater. Interfaces 2013, 5, 3487-3493. [CrossRef]

20. Kavan, L.; O’Regan, B.; Kay, A.; Grätzel, M. Preparation of $\mathrm{TiO}_{2}$ (anatase) films on electrodes by anodic oxidative hydrolysis of $\mathrm{TiCl}_{3}$. J. Electroanal. Chem. 1993, 346, 291-307. [CrossRef]

21. Zhan, Z.Y.; An, J.N.; Zhang, H.C.; Hansen, R.V.; Zheng, L.X. Three-dimensional plasmonic photoanodes based on Au-embedded $\mathrm{TiO}_{2}$ structures for enhanced visible-light water splitting. ACS Appl. Mater. Interfaces 2014, 6, 1139-1144. [CrossRef]

22. Chang, H.M.; Yang, Y.J.; Li, H.C.; Hsu, C.C.; Cheng, I.C.; Chen, J.Z. Preparation of nanoporous $\mathrm{TiO}_{2}$ films for DSSC application by a rapid atmospheric pressure plasma jet sintering process. J. Power Sources 2013, 234, 16-22. [CrossRef]

23. Wang, Y.; Wan, J.; Ding, J.; Hu, J.S.; Wang, D. A rutile $\mathrm{TiO}_{2}$ electron transport layer for the enhancement of charge collection for efficient perovskite solar cells. Angew. Chem. Int. Ed. 2019, 58, 9414-9418. [CrossRef]

24. Ke, J.C.; Wang, Y.H.; Chen, K.L.; Huang, C.J. Effect of organic solar cells using various power $\mathrm{O}_{2}$ plasma treatments on the indium tin oxide substrate. J. Colloid Interface Sci. 2016, 465, 311-315. [CrossRef]

25. Jeon, N.J.; Noh, J.H.; Kim, Y.C.; Yang, W.S.; Ryu, S.; Seok, S.I. Solvent engineering for high-performance inorganic-Organic hybrid perovskite solar cells. Nat. Mater. 2014, 13, 897-903. [CrossRef]

(C) 2020 by the authors. Licensee MDPI, Basel, Switzerland. This article is an open access article distributed under the terms and conditions of the Creative Commons Attribution (CC BY) license (http://creativecommons.org/licenses/by/4.0/). 